\title{
Essays
}

\section{Teetering on the Brink: Between Death and Life}

\author{
Mumia Abu-Jamal $\uparrow+\dagger$
}

For there to be equivalence, the death penalty would have to punish a criminal who had warned his victim of the date at which he would

$\dagger$ Mr. Abu-Jamal is an African American on Death Row in Pennsylvania. He was sentenced to death in 1982 for the shooting and killing of a police officer. During the incident Mr. Abu-Jamal suffered a serious gunshot wound and was badly beaten. At the time, he had no police record and was a prominent radio journalist in Philadelphia and the president of the local chapter of the Association of Black Journalists. Mr. Abu-Jamal was a member and spokesperson of the Black Panther Party in the early 1970's and has been a supporter of the MOVE organization. He has challenged his conviction and sentence on numerous grounds, including: the prosecutor's use of peremptory challenges to exclude Black jurors and the court's refusal to permit Mr. Abu-Jamal's challenge for cause of a juror who admitted uncertainty as to whether he could be open-minded; the court's permitting the prosecutor to conduct a cross-examination of a character witness about her "sympathy to cop killers"; the court's permitting the prosecutor to present Mr. Abu-Jamal's political views and controversial group associations to the jury (the ACLU and National Conference of Black Lawyers submitted an amici curiae brief challenging these references on First Amendment grounds); the prosecutor's closing argument asking for the death penalty in which he told the jury that Mr. Abu-Jamal would have "appeal after appeal" and that the jury was not being "asked to kill anybody." This past summer the Partisan Defense Committee organized a series of international protests on Mr. Abu-Jamal's behalf. Over 35,000 people have signed petitions to the Governor of Pennsylvania urging clemency. Hundreds of prominent individuals have written letters on his behalf, including U.S. Representative Ron Dellums, Amnesty International Executive Director John Healey, Southern Christian Leadership Conference President Rev. Joseph Lowery, and Philadelphia Union Local 1034 President Charles Valenta. The Supreme Court denied Mr. Abu-Jamal's petition for certiorari, and at present he is preparing a petition for postconviction relief. Since his incarceration he has written articles on legal and social issues and prison life for several newspapers and periodicals, including The Nation. -Ed.

it The author is limited by space for acknowledgments, and his thanks are many. To the tens of thousands who have signed petitions on his behalf, a profound thanks to all; to the Partisan Defense Committees worldwide, gratitude for their remarkable organizing prowess; to Nan P. Pow, National Conference of Black Lawyers and beyond; to the martyrs of May 13,1985, bombed into oblivion by this system-to Nick, Tree, Rad, Rhonda, Ray, Tomasso, Katrina, Lil Phil, to them all; to John Africa, my loving reverence; to Rachel; to Denizens of Death Rows; to the imprisoned worldwide, aching for freedom; to my mate, Wadiya-love, for keeping the flame of resistance burning. 
inflict a horrible death on him and who, from that moment onward, had confined him at his mercy for months. Such a monster is not encountered in private life.

Camus $^{1}$

\section{I. "YARD IN!"}

The last "yard" of the day is finally called. "Capitals! Fourth, fifth, and sixth tier-YARD-UP!" the corpulent correctional officer bellows, his rural accent alien to the urban ear.

One by one, cells are unlocked for the daily trek from cell to cage. Each man is pat-searched by guards armed with batons, then scanned by a metal detector.

Once the inmates are encaged, the midsummer sky rumbles, its dark clouds swell, pregnant with power and water. A bespectacled "white shirt" turns his pale face skyward, examining nature's quickening portent. The rumbles grow louder as drops of rain sail earthward, splattering steel, brick, and human.

"Yard in!," the white shirt yells, sparking rumbling murmurs of resentment among the men.

"Yard in?!—shit, man-we just got out here!"

The guards adopt a cajoling, rather than threatening, attitude. "C'mon, fellas-yard in, yard in. Ya know we can't leave y'uns out here when it gits ta thunderin' an' lightnin'."

"Oh—why not? Y'all 'fraid we gonna get ourself electrocuted?," a prisoner asks.

"Ain't thatta bitch?" another adds. "They must be afraid that if we do get electrocuted by lightnin', they won't have no jobs and won't get paid!"

A few guffaws, and the trail from cage to cell thickens.

Although usually two hours long, today's yard barely lasts ten minutes, for fear that those condemned to death by the state may perish, instead, by fate.

For approximately 2400 people locked in state and federal prisons, life is unlike that in any other institution. For these are America's "condemned," those who bear a stigma far worse than "prisoner." These are America's Death Row residents: men and women who walk the razor's edge between half-life and certain death in thirty-four states or under the jurisdiction of the United States. ${ }^{2}$ The largest Death Row is in Texas (324 people: 120 African Americans, 144 whites, 52 Hispanics, 4 Native Americans, and 4 Asian Americans); the small-

1. A. CAMUS, Reflections on the Guillotine, in RESISTANCE, REBELLION, AND DEATH 199 (O'Brien trans. 1961) (posthumous collection of essays).

2. NAACP LEGAL DEFENSE AND EDUCATIONAL FUND, DEATH ROW, U.S.A. (quarterly update, Sept. 21,1990 ) [hereinafter DEATH ROW, U.S.A.]. 
est are in Connecticut ( 2 whites), New Mexico (1 Native American, 1 white), and Wyoming ( 2 whites). ${ }^{3}$

You will find a blacker world on Death Row. African Americans, a mere twelve percent of the national population, compose about forty percent of the Death Row population. ${ }^{4}$ There, too, you will find this writer.

\section{CONTROL}

It is from Pennsylvania's largest Death Row at the State Correctional Institute at Huntingdon, in rural, south-central Pennsylvania, that I write. In the Commonwealth, I am but one of 123 persons who await death. I have lived in this barren domain of death since the summer of 1983. For several years now I have been assigned "DC" (disciplinary) status for daring to abide by my faith, the teachings of John Africa, and in particular, for refusing to cut my hair. ${ }^{5}$ For this I have been denied family phone calls, and on occasion, I have been shackled for refusing to violate my beliefs. ${ }^{6}$

Life here oscillates between the banal and the bizarre.

Unlike other prisoners, Death Row inmates are not "doing time." Freedom does not shine at the end of the tunnel. Rather, the end of the tunnel brings extinction. Thus for many here, there is no hope.

As in any massive, quasi-military organization, reality on the Row is regimented by rule and regulation. As against any regime imposed on human personality, there is resistance, but far less than one might expect.

For the most part, Death Row prisoners are the best behaved and least disruptive of all inmates. It is also true, however, that there is little opportunity to be otherwise, given that many "death units" operate on the " $22+2$ " system:

3. Id. at $13,23,30,34$.

4. Id. at 1 .

5. John Africa is the founder of MOVE, an organization formed in 1972 as the "Christian Movement for Life." Adherents to MOVE ideology reject the social order and its legal authority. Followers of the teachings of John Africa place faith in "God-given natural law," wear their hair in dreadlocks, and reject technology, formal education, and other products of an unequal, unjust society. See Washington, MOVE: A Double Standard of Justice?, 1 YALE J.L. \& LIBERATION 67, 67-70 (1989).

6. MOVE members incarcerated in Pennsylvania prisons are often given disciplinary status for refusing to cut their hair; some have been denied parole for refusing to agree to stipulations forbidding them to associate with other members upon release. Id. at 68; see, e.g., Moushey, Inmate's Rehabilitation Counts for Little, Pittsburgh Post-Gazette, Sept. 4, 1990, at 1 (MOVE supporter Richard Garland, considered a rehabilitated model prisoner by correction officials, denied parole based on refusal to disassociate himself from MOVE members including his wife). Such actions by the state violate constitutional rights to freedom of religion, speech, and association. See, e.g., Garland v. Sullivan, 2 Civ. Trial Manual (BNA) No. 5, at 108-09 (Apr. 9, 1986) (E.D. Pa., No. 80-2350, Mar. 5, 1986) (jury in civil case brought by inmate against prison guards finds MOVE is religious organization within meaning of First Amendment). Contra Africa v. Pennsylvania, 662 F.2d 1025 (3d Cir. 1981) (upholding state prison's rejection of MOVE member's special dietary request on ground that MOVE fails to qualify as religion within meaning of First Amendment). 
twenty-two hours locked in cell, followed by two hours of recreation out of cell. Outdoor recreation takes place in a cage, ringed with double-edged razor wire-the "dog pen."

All Death Rows share a central goal: "human storage" in an "austere world in which condemned prisoners are treated as bodies kept alive to be killed."7 Pennsylvania's Death Row regime is among America's most restrictive, rivaling the infamous San Quentin death unit for the intensity and duration of restriction. A few states allow four, six, or even eight hours out-of-cell, prison employment, or even access to educational programs. Not so in the Keystone State.

Here, one has little or no psychological life. Here, many escape death's omnipresent specter only by way of common diversions-television, radio, or sports. Here, TV's are allowed, but not typewriters: one's energies may be expended freely on entertainment, but a tool essential for one's liberation through judicial process is deemed a "security risk."

One inmate, more interested in his life than his entertainment, argued forcefully with prison administrators for permission to buy a non-impact, nonmetallic, battery-operated typewriter. Predictably, permission was denied for "security" reasons. "Well, what do y'all consider a thirteen-inch piece of glass?" the prisoner asked. "Ain't thatta 'security risk'?"

"Where do you think you'll get that from?" the prison official demanded.

"From my TV!"

Request for typewriter denied.

TV is more than a powerful diversion from a terrible fate. It is a psychic club used to threaten those who dare resist the dehumanizing isolation of life on the Row. To be found guilty of an institutional infraction means one must relinquish it.

After months or years of non-contact visits, few phone calls, and ever decreasing communication with one's family and others, many use TV as an umbilical cord, a psychological connection to the world they have lost. They dread its separation and depend on it, in the way that lonely people turn to TV for the illusion of companionship. For many, loss of TV is too high a price to pay for any show of resistance.

\section{Humiliation}

Visits are an exercise in humiliation.

7. Johnson \& Carroll, Litigating Death Row Conditions: The Case for Reform, in PRISONERS AND THE LAW 8-3, 8-5 (I. Robbins ed. 1988) (quoting R. Johnson, Death Row Confinement: The Psychological and Moral Issues 5 (unpublished paper presented at colloquium on the death penalty at Towson State University, Mar. 10, 1983)). 
In Pennsylvania, as in many other death states, non-contact visits are the rule. ${ }^{8}$ It is not just a security rule; it is a policy and structure which attempts to sever emotional connection by denying physical connection between the visitor and the inmate. Visits are conducted in a closed room, roughly eighty square feet in size. The prisoner is handcuffed and separated by a partition of shatterproof glass, steel trim, and wire mesh.

What visitors do not see, prior to the visit, is a horrifying spectacle-the body-cavity strip search. Once the prisoner is naked, the visiting-room guard spits out a familiar cadence:

"Open yer mouth-

Stick out your tongue-

You wear any dentures?

Lemme see both sides of your hands-

Pull your foreskin back-

Lift your sac-

Turn around-

Bend over-

Spread your cheeks-

Bottom of yer feet-

Get dressed."

Several prisoners have protested administratively that such searches are unreasonable, arguing that body-cavity strip searches before and after noncontact visits cannot be justified. Either allow contact visits, they argue, or halt the body-cavity strip searches. But prison officials have responded to this proposal in the same manner with which they have responded to repeated calls by the condemned for allowance of typewriters: refusal, due to the "security risk."

For the visitor, too, such visits are deeply disturbing.

In Rhem v. Malcolm, ${ }^{9}$ the often-cited case on prison conditions in New York, Judge Lasker quoted expert testimony from Karl Menninger, the late psychiatrist, who described non-contact visiting as " the most unpleasant and most disturbing detail in the whole prison," "and a practice which constitutes " "a violation of ordinary principles of humanity." ${ }^{10}$ Dr. Menninger stated:

8. Inmates on Death Row in Georgia, Florida, and Alabama are permitted contact visits. Id. at 8-20. The late Florida Corrections Chief, Louis Wainwright, consistently defended the efficacy of contact visits for noncapital-offense state prisoners. See Miller v. Carson, 401 F. Supp. 835,884 (M.D. Fla. 1975), aff $d$ in part, 563 F.2d 741 (5th Cir. 1977) ("It was defendant Wainwright's opinion that contact visits are desirable and an effective rehabilitative tool.").

9. 371 F. Supp. 594 (S.D.N.Y. 1974).

10. Id. at 602 . 
“' [I]t's such a painful sight that I don't stay but a minute or two as a rule. It's a painful thing .... I I feel so sorry for them, so ashamed of myself that I get out of the room." "'11

The ultimate effect of non-contact visits is to weaken, and finally to sever, family ties. Through this policy and practice the state skillfully and intentionally denies those it condemns a fundamental element and expression of humanity-that of touch and physical contact-and thereby slowly erodes family ties already made tenuous by the distance between home and prison. Thus a prisoner is as isolated psychologically as he is temporally and spatially. By state action, he becomes "dead" to those who know and love him, and therefore, dead to himself. For who is a person, but for his relations and relationships?

Hurled by judicial decree into this netherworld of despair, forcefully separated from relationships, overcome by the dual shame of their station and the circumstances of the crime which led them to death's door, a few succumb to the shady release of suicide. ${ }^{12}$ Some fight Sisyphian battles, struggling to prove their innocence and reverse unjust convictions. Others live as they are treated-as " shadows of [their] former selves, in a pantomime of life, human husks." "13

To such men and women, the actual execution is a fait accompli, a formality already accomplished in spirit, where the state concludes its premeditated drama by putting the "dead" to death a second time.

\section{POLITICS AND "JUSTICE" OF DEATH}

Although it might be said fairly that many people, both in and outside of prison, are utterly uninformed as to the workings of the U.S. Supreme Court, there are some among those on Death Row who watch the Court with acute attention. For them, the sudden resignation of Justice William J. Brennan, Jr. comes as crushing news after a season of sorrow. The recent spate of losses suffered by capital litigators spells all but certain doom for those who continue to petition the present Court for legal relief. ${ }^{14}$

11. Id. (citation omitted). Dr. Menninger's comments regarding the impact of non-contact visitation were in reference to the Manhattan House of Detention, a county jail facility.

12. DEATH ROW, U.S.A., supra note 2, at 1 (counting twenty-eight Death Row inmate suicides in U.S. since Jan. 1, 1973).

13. Johnson \& Carroll, supra note 7, at 8-8 (citing R. Johnson, Death Row Confinement, supra note 7, at 16-17 (quoting Death Row inmate Philip Brasfield on slow process of "dehumanization" which occurs)).

14. These cases, even with Justice Brennan sitting, reveal an ill-disguised judicial hostility to issues which once seemed meritorious. See, e.g., Saffle v. Parks, 110 S. Ct. 1257 (1990) (scope of collateral review does not include finding that instruction to jury to "avoid any influence of sympathy" is unconstitutional); Boyde v. California, 110 S. Ct. 1190 (1990) (instruction that jury "shall impose a sentence of death" if it finds that aggravating circumstances do not outweigh mitigating circumstances does not violate defendant's constitutional right to individualized assessment of appropriateness of death penalty); Blystone v. Pennsylvania, 110 S. Ct. 1078 (1990) (statute requiring imposition of death penalty where aggravating circumstances outweigh mitigating ones is not unconstitutional); McCleskey v. Kemp, 481 U.S. 279 (1987) (statistical data 
Where the issue of the death penalty is concerned, law follows politics, and conservatives won the sociopolitical battles of the 1980's on the basis of an agenda which included a ringing endorsement of capital punishment. The venerated principle of stare decisis meant little in the politically charged judicial arena. Statistical methodology and scientific and sociological studies, once valued tools for challenging state practice, now serve as meaningless academic exercises.

$M c$ Cleskey v. Kemp ${ }^{15}$ was the clincher. The Supreme Court majority, Justice Powell writing, assumed the validity of the so-called "Baldus study," which presented mounds of powerful statistical data demonstrating gross racial disparity in Georgia's death penalty tallies, but rejected the study's clear implications. ${ }^{16}$

Justice Brennan's dissent telescoped the Baldus study's meaning: defendants charged with killing whites are 4.3 times more likely to be sentenced to die as defendants charged with killing Blacks; six of every eleven defendants convicted of killing a white would not have received a death sentence had their victim been Black. ${ }^{17}$ Thus the study showed that "there was a significant chance that race would play a prominent role in determining if [a defendant] lived or died." 18

The majority's perambulations to its eventual rejection of that which it could hardly deny - that the race of the victim is a primary factor in determining whether a defendant lives or dies-proved the potency of the old adage offered by the satirical character, Mr. Dooley, who shrewdly observed: "No matther whether th' constitution follows th' flag or not, th' supreme coort follows th' iliction returns." "19

showing, inter alia, that Blacks convicted of killing whites more likely to receive death penalty than other defendants did not demonstrate violation of petitioner's constitutional rights since petitioner failed to establish evidence that racial considerations played role in his case); Lockhart v. McCree, 476 U.S. 162 (1986) (removal for cause of persons opposed to death penalty does not violate petitioner's right to jury selected from a fair cross-section of the community); Wainwright v. Witt, 469 U.S. 412 (1985) (removal for cause of person opposed to death penalty does not violate petitioner's Sixth and Fourteenth Amendment rights to trial by impartial jury where judge made finding that excused juror's views would prevent or substantially impair the performance of her duties).

15. 481 U.S. 279 (1987).

16. In support of his claim that the Georgia capital sentencing process was administered in a racially discriminatory manner in violation of the Eighth and Fourteenth Amendments, McCleskey submitted a statistical study (the Baldus study) which examined over 2000 Georgia murder cases from the 1970's. Id. at 286. The Court's majority assumed the study's statistical validity for purposes of decision. Id. at $291 \mathrm{n} .7$. The dissenters, however, were persuaded that the statistical evidence was valid. See id. at $345 \&$ n.l (Blackmun, J., dissenting).

17. Id. at 321 (Brennan, J., dissenting).

18. Id.

19. F. DUNNE, The Supreme Court's Decisions, in MR. DOOLEY ON THE CHOICE OF LAW 47, 52 (E. Bander ed. 1963) (collection of newspaper essays from the turn of century). On capital punishment, Mr. Dooley observed: "I don't believe in capital punishment . . . but 'twill niver be abolished while th' people injye it so much." F. DuNNE, The Law's Delays, in id. at $37,38$. 
McCleskey's claim, based on sophisticated statistical and multiple regression analysis, buttressed by "our understanding of history and human experience,"20 was not disproved by the McCleskey Court; rather, it was rejected out of fear. In rejecting the conclusion that the facts established an unconstitutional infirmity, Justice Powell noted with alarm, that "McCleskey's claim, taken to its logical conclusion, throws into serious question the principles that underlie our entire criminal justice system."21

\section{Precisely.}

Because McCleskey dared question the fundamental fairness of the entire system, his claims were answered with rejection.

Delbert Tibbs, an African American divinity student, once found himself tossed-in with Death Row prisoners in Florida. Convicted by an all-white jury in 1974 for a rape and related murder, he spent three harrowing years in death's shadow before appellate reversal.

In speaking about his jury, he observed:

PEER: one of equal rank; one among equals. I knew the definition of that word, and there was nothing remotely akin to this meaning existing between me and these seven hard-eyed White Men and five cold-eyed White Women who made up this jury of my "peers."

I knew that any peerage that they comprised, as indeed they did comprise such a thing, totally excluded me, at least, in their eyes. ...

...

... Peers, indeed.

I'm sure that in the eyes of that jury I was not just another human being. Oh, no. I was dangerous, because, darker. I didn't belong . . . .22

On the McCleskey decision, Tibbs noted:

Apparently, that Justice of the United States, writing for the majority, thinks that the United States is not two separate societies, one black and one white, and quite unequal....

... Justice is not meted out without regard to race, sex, economics, or previous condition of serviture....

That Justice was speaking as if there were no Civil War and no chattel slavery. He spoke as if there were no history of lynchings, as

20. 481 U.S. at 328 (Brennan, J., dissenting).

21. 481 U.S. at 314-15.

22. Tibbs, From Seminary To Cell Block, in A SAga of Shame: Raclal Discrmmation and the DEATH PENALTY 16 (publication of Let Live, Quixote Center 1989). 
if there were no Dred Scott decision, no Medgar Evers, Little Rock, nor

"Bombingham." Memphis didn't happen in that "America." 23

What does happen, in this America, is the cheapening of Black life and the placing of a premium upon white life. As Justice Brennan's eloquent dissent in $\mathrm{McCl}$ leskey argues, the fact that this practice may be customary does not make it constitutional.

To do justice, one must consistently battle, in Brennan's words, "a fear of too much justice."24 Finding that fear firmly entrenched, he framed his arguments, not merely as counters to positions with which he passionately disagreed, but also as warnings for the future, a day not yet dawned:

It is tempting to pretend that minorities on death row share a fate in no way connected to our own, that our treatment of them sounds no echoes beyond the chambers in which they die. Such an illusion is ultimately corrosive, for the reverberations of injustice are not so easily confined. ...

The Court's decision today will not change what attorneys in Georgia tell other Warren McCleskeys about their chances of execution. Nothing will soften the harsh message they must convey, nor alter the prospect that race undoubtedly will continue to be a topic of discussion. McCleskey's evidence will not have obtained judicial acceptance, but that will not affect what is said on death row. However many criticisms of today's decision may be rendered, these painful conversations will serve as the most eloquent dissents of all. ${ }^{25}$

Ironically, perhaps, the "eloquent dissents" of pro se Court-watchers are commonly delivered in the winning or losing of a bet: inmates on the Row often wager with one another on the outcome of judicial decisions. But as the real stakes riding on any given outcome are high, objective predictions are rarely possible.

By viewing every decision through the prism of politics, I never lost a bet-even in cases where "jailhouse lawyers" claimed to have "the law" on their side. There is, of course, no satisfaction in such victories: every bet won has been a case lost; every case lost a step closer to death. My predictions, based on political winds rather than law, have earned me the enmity of those jailhouse lawyers who continue to place faith in legal precedents and principles despite their growing pile of lost wagers.

23. Id. at 16-17.

24. McCleskey, 481 U.S. at 339 (Brennan, J., dissenting).

25. Id. at $344-45$. 


\section{DEATH MaRCh AND LESSONS UNLEARNED}

There is a quickening upon the nation's Death Rows of late, a picking up of the pace of the march toward death. The political prod is sparking movement, and judges in death cases are beginning to find themselves under increasing pressure to make the final judgment.

As murder rates rise in American cities, so too does the tide of fear. Both politicians and judges continue to ride that tide which washes towards the execution chamber's door. No matter that of the ten states with the highest murder rate, eight of them lead the country in executions which supposedly "deter"; no matter that of the ten states with the lowest murder rate, only one (Utah) has executed anyone since $1976 .{ }^{26}$ No matter that the effectiveness of the death penalty is not really debated; no matter that the contention that the death penalty makes citizens "safer" is no longer seriously argued.

Habeas corpus, fundamental to English law since the reign of King Charles and to the United States Constitution since its inception, now faces evisceration under the hand of the Chief Justice of the Supreme Court, ${ }^{27}$ a possibility unthinkable just a few years ago. Many of the "condemned," with constitutional error rife throughout their records, will soon be executed without meaningful review.

States that have not slain in a generation now ready their machinery: generators whine, poison liquids are mixed and gases are measured and readied, silent chambers await the order to smother life. Increasingly, America's Northern states now join the rushing pack, anxious to re-link themselves with their pre-Furman ${ }^{28}$ heritage.

\section{Deterrence?}

The March, 1988 Florida execution of Willie Darden, exceedingly wellpublicized here and abroad, should have had enormous deterrent effect accord-

26. Compare Murder in the City, USA Today, Aug. 6, 1990, at 3A (FBI and U.S. Dep't of Justice data on murder rates by state) with NATIONAL COALITION TO ABOLISH THE DEATH PENALTY, UNITED STATES EXECUTIONS (data sheet of Sept. 25, 1990) (listing executions by state and names and dates of execution of people put to death since 1976).

27. Rehnquist has long been impatient with the slow pace of state executions, stating that persistent challenges by capital defendants undermine the "rule of law" and make a "mockery" of the criminal justice system. Burt, Disorder in the Court: The Death Penalty and the Constitution, 85 MICH. L. REV. 1741, 1782$83,1791-92,1811$ (1987). Recently, Rehnquist has been in the forefront of legislative efforts to "reform" habeas corpus in order to grease the skids to death. See Chief Justice Endorses Powell Committee Report on Habeas Reform in Capital Cases, [Apr.-Sept.] Crim. L. Rep. (BNA) No. 47, at 1159 (May 23, 1990) (endorsement of proposal to restrict capital defendants to single opportunity at federal level for collateral review of sentence).

28. Furman v. Georgia, 408 U.S. 238 (1972) (per curiam) (imposition and carrying out of death penalty in cases before the Court would constitute cruel and unusual punishment in violation of Eighth and Fourteenth Amendments). 
ing to capital theories. But less than eleven hours after 2000 volts coursed through Darden's manacled flesh, a Florida corrections officer, well-positioned to absorb and understand the lessons of the state ritual, erupted in a jealous rage and murdered a man in the maternity wing of a hospital. ${ }^{29}$

Seems like a lesson well learned to me.

29. Breslin, State Shouldn't Be in the Killing Business, The Sunday News (Lancaster, PA), Mar. 20, 1988 , at A15. 


$$
\text { . }
$$

